\title{
COMMENT
}

\section{ENTITLEMENT, ENJOYMENT, AND DUE PROCESS OF LAW}

This Comment will discuss the following cases:

Case 1: $A$, a school teacher in State $\mathrm{X}$, is tenured and can be dismissed only for cause. The local school board, claiming that $A$ 's alleged insubordination is cause for dismissal, summarily fires him. Rather than contesting the board's claim in state court, $A$ commences an action in federal district court, alleging that the board's precipitate action in dismissing him without a hearing has deprived him of property without due process of law, in violation of the fourteenth amendinent. The district court grants the board's motion to dismiss for failure to state a claim on which rehef can be granted, and $A$ appeals. ${ }^{1}$

Case 2: $B$, also a teacher in State $\mathrm{X}$, has been employed for several years pursuant to annual contracts, and the local school board has offered to renew her contract for the coming year. Before $B$ accepts, the board rescinds its offer, thereby precluding her continued employment, and gives no reasons for its action. $B$ files suit in federal district court, alleging that the school board's fail-

1. These are, with some minor embellishments, the facts alleged by the plaintiff in Perry v. Sindermann, 408 U.S. 593 (1972), except that in Perry, the tenure agreement relied on was one implied-in-fact, rather than one written into a statute. Id. at 599-600. Such an agreement might arise out of commonly accepted, informal practices, carried out over a long course of usage by a school board. Id. at 601-02. For discussions of Perry see, e.g., Note, Public Employees' Right to a Pre-Termination Hearing Under the Due Process Clause, 48 IND. L.J. 127 (1972); Comment, Public School Teachers and the Limits of Due Process Protection, 61 KY. L.J. 830 (1973).

For a discussion of the procedural rights of public employees, see Van Alstyne, The Constitutional Rights of Teachers and Professors, 1970 DUKE L.J. 841; Van A1styne, The Constitutional Rights of Public Employees: A Comment on the Inappropriate Uses of an Old Analogy, 16 U.C.I.A.I. Rev. 751 (1969); Note, Application of the Constitutional Privacy Right to Exclusions and Dismissals from Public Employment, 1973 DUKR L.J. 1037; Comment, Due Process and Public Employment in Perspective: Arbitrary Dismissals of Non-Civil Service Employees, 19 U.C.L.A.L. Rev. 1052 (1972). 
ure to renew her contract, without giving her a hearing or notice of the charges against her, has deprived her of property without due process of law. As in case 1, the board's motion to dismiss is granted, and $B$ appeals. $^{2}$

Case 3: While $A$ is awaiting the result of his appeal, he has no source of incoine. After he has applied for and received welfare payments for several months, the state commissioner of welfare cuts him from the rolls, on the ground that he failed froin the beginning to meet the statutory standards for eligibility. $A$ sues the commissioner in federal court, claiming that, under the due process clause, he is entitled to a hearing before his benefits are terminated. He loses at the pleading stage and appeals. ${ }^{3}$

Case 4: $B$ is also penniless pending the outcome of her appeal and applies for welfare. The commissioner finds her to be ineligible for the same reasons he found $A$ to have been initially ineligible, and therefore denies her application. $B$ 's request for a hearing at which she can argue that she does meet the requirenients of the statute is also denied. She goes to federal court to compel the commissioner to grant her such a hearing, her complaint is dismissed, and she appeals, pressing her due process claim. ${ }^{4}$

Case 5: Poverty-stricken, lopeless and desperate, $A$ commits armed robbery, and is arrested, convicted and sentenced to prison for 15 years. After serving five years

2. This is essentially the situation the Court found in Board of Regents of State Colleges v. Roth, 408 U.S. 564 (1972), assuming that the school board's conduct in renewing $B$ 's contract in past years is insufficient to give rise to the kind of impliedin-fact tenure agreement rehed on in Perry v. Sindermann, 408 U.S. 593 (1972). For a discussion of Roth, see 73 CoLUM. L. REV. 882 (1973).

3. This case is basically Goldberg v. Kelly, 397 U.S. 254 (1970). Actually, in Goldberg, the state had granted a termination hearing, but only after the payment of benefits had been suspended. The plaintiff had demanded a prior hearing. The distinction is largely irrelevant since the plaintiff's demand that the federal courts overturn state procedures necessitated a preliminary determination as to whether the due process clause applied at all to a termination of welfare benefits. For a discussion of the implications of Goldberg, see Scott, The Reality of Procedural Due ProcessA Study of the Implementation of Fair Hearing Requirements by the Welfare Caseworker, 13 WM. \& MARY L. REv. 725 (1972).

4. This case has apparently not been litigated. See generally Parsons-Lewis, Due Process in Parole-Release Decisions, 60 CALIF. L. REv. 1518 (1972). 
of his sentence, $A$ is paroled. Two years later, $A$ 's parole officer recommends revocation of his parole for allegedly teaching without a license. $A$ is immediately returned to prison. His attorney seeks to persuade the federal courts to compel the state parole board to give him a hearing, which $A$ feels will establish his innocence of the claimed infraction. In view of the disposition of $A$ 's two previous suits, the judge dismisses this action as frivolous, and $A$ appeals on the ground that he has been deprived of liberty without due process. $^{5}$

Case 6: $B$ is mistakenly identified by a witness as $A$ 's accomplice and is also convicted of armed robbery and sentenced to 15 years in prison. Under State X's parole scheme, $B$ is eligible for parole after serving five years of her sentence, and the great majority of first-offenders like $B$ are in fact paroled after serving this minimum term. Five years pass, then six, then seven, but despite $B$ 's frequent petitions, the parole board takes no action on her case, giving no reason for its decision. $B$ asks the federal district court to compel the board to grant her a hearing. She loses for the third time and appeals, urging that she is bemg deprived of her hiberty without due process of law. ${ }^{6}$

Under the courts' current interpretation of the due process clause, it is likely that $A$ will win all three of his appeals, while $B$ will lose all three of hers. This Comment will attempt to (1) explain the bases for the courts' distinction between the situations of $A$ and $B$, the so-called "entitlement" and "present enjoyment" doctrines;" (2) expose the inconsistencies and logical fallacies which seem to be inherent $\mathrm{m}$ these doctrines; $;$ (3) point out the possible injurious consequences of continued rehance on the doctrines; ${ }^{9}$ (4) speculate briefly as

5. With dramatic variations, these are the basic facts of Morrissey v. Brewer, 408 U.S. 471 (1972). Actually, Morrissey was convicted of passing bad checks, sentenced to not more than seven years in prison, and paroled after one year. His parole was summarily revoked seven months later for, inter alia, buying and operating a car without permission and under an assnmed name. Id. at 472-73.

6. These facts are similar to those of a number of reported cases, including Scarpa v. United States Bd. of Parole, 477 F.2d 278 (5th Cir. 1973), and Menechino v. Oswald, 430 F.2d 403 (2d Cir. 1970), cert. denied, 400 U.S. 1023 (1971).

7. See notes $12-60$ infra and accompanying text.

8. See notes 61-96 infra and accompanying text.

9. See notes 97-107 infra and accompanying text. 
to why the courts have chosen to resort to the doctrines; ${ }^{10}$ and (5) suggest an alternative approach to resolving the questions presented in cases 1 through $6 .{ }^{11}$

\section{The Emerging Contours of Due Process: Entitlement AND PRESENT ENJOYMENT}

"[N]or shall any State deprive any person of life, liberty, or property, without due process of law . . .."12

A layman might suppose that life, liberty, and property include everything of which a person might be deprived, and that therefore the due process clause stands for the proposition that wlienever a state takes action which is in any way detrimental to a person, it must do so with due process of law. If this were true, the foci of judicial inquiry would then be the meanings of the word State $^{13}$ and the phrase due process of law, ${ }^{14}$ and there would be little need for interpretation

10. See notes 108-10 infra and accompanying text.

11. See notes 111-25 infra and accompanying text.

12. U.S. ConsT. amend. XIV, $\$ 1$.

One might be able to avoid the problems involved in asserting claims under the due process clause (to be discussed in this Comment) by resorting instead to the equal protection clause, since the two clauses are to some extent interchangeable. See Van Alstyne, The Demise of the Right-Privilege Distinction in Constitutional Law, 81 HARv. I. REv. 1439, 1454-57 (1968). Nevertheless, effort may be well spent in attempting to expose the doctrinal difficulties underlying current due process law because (1) some factual situations more naturally lend themselves to treatment under the due process clause (this is essentially the suggestion of Professor Michelman in Foreword: On Protecting the Poor Through the Fourteenth Amendment, 83 HARv. L. REv. 7 (1969)); (2) the Court itself has chosen to give many of these cases a due process analysis (see, e.g., cases cited in note 19 infra), and (3) recent decisions suggest a Supreme Court predilection for a due process approach, and an accordingly greater chance of success for litigants who pursue this tack. Compare Rodriguez v. San Antonio Independent School Dist., 411 U.S. 1 (1973) (equal protection argument rejected) with Roe v. Wade, 410 U.S. 113, 152-64 (1973) (substantive due process argument accepted). See also Vlandis v. Klime, 412 U.S. 441 (1973) (due process clause used to strike down what was in effect discrimination against recent interstate migrants, where previous cases such as Shapiro v. Thompson, 394 U.S. 618 (1969) would have seemed to indicate an equal protection analysis).

13. The meaning of the word "State" has in fact been extensively bitigated. See Lloyd Corp. v. Tanner, 407 U.S. 551 (1972); Palmer v. Thompson, 403 U.S. 217 (1971); Burton v. Wilmmgton Parking Authority; 365 U.S. 715 (1961); Civil Rights Cases, 109 U.S. 3 (1883); Black, Foreword: 'State Action,' Equal Protection, and California's Proposition 14, 81 Harv. L. Rev. 69 (1967); Van Alstyne \& Karst, State Action, 14 Stan. L. Rev. 3 (1961); Lewis, The Meaning of State Action, 60 Colum. L. REv. 1083 (1960).

14. There have been a multitude of cases delineating just what process is due in different factual contexts. See, e.g., Bell v. Burson, 402 U.S. 535 (1971) (revocation of driver's license); Boddie v. Connecticut, 401 U.S. 371 (1971) (institution of divorce proceedings); Wisconsin v. Constantineau, 400 U.S. 433 (1971) (public posting of names of reputed habitual drunkards); Goldberg v. Kelly, 397 U.S. 254 (1970) (termi- 
'of the words life, liberty, and property. Under this view, which will be examined with approval in Part $V$ of this Comment, ${ }^{15}$ the seriousness of the deprivation, together with other factors, ${ }^{16}$ might reasonably determine what "process" must be observed in each situation.

In several recent cases, however, the Supreme Court has inade it clear that there is no necessary equivalence between simple detriment and a deprivation of life, liberty, or property. ${ }^{17}$ While the Court has shown a willingness to expand its concept of property to include certain forms of government largess, ${ }^{18}$ it has at the same time insisted that a person must have an "entitlement" to the thing of which he has been deprived, in order to qualify for due process protection. ${ }^{19}$ The litigant must show support for his claim of entitlement in state statutory or common law. ${ }^{20}$ Closely related to the entitlement concept is the principle enunciated by several courts ${ }^{21}$ that due process safeguards are applicable only to deprivations of presently enjoyed life, liberty, or property, and not to a state's refusal to grant a benefit de novo.

\section{Protected Interests}

The seventeen words of the fourteenth amendment due process

nation of welfare benefits); Sniadach v. Family Fin. Corp., 395 U.S. 337 (1969) (garnishment of wages); Pickering v. Board of Educ., 391 U.S. 563 (1968) (dismissal of teacher for nraking statenent critical of school board).

15. See notes 113-16 infra and accompanying text.

16. See notes 121-24 infra and accompanying text.

17. Perry v. Sindermann, 408 U.S. 593 (1972); Board of Regents of State Colleges v. Roth, 408 U.S. 564 (1972); Morrissey v. Brewer, 408 U.S. 471 (1972); Fuentes v. Shevin, 407 U.S. 67 (1972), discussed in text accompanying notes 111-12 infra.

18. See Goldberg v. Kelly, 397 U.S. 254 (1970) (public assistance); cf. Vlandis v. Kline, 412 U.S. 441 (1973) (tuition subsidy). See also Escalera v. New York City Housing Authority, 425 F.2d 853 (2d Cir.), cert. denied, 400 U.S. 853 (1970) (subsidized public housing). See notes 38-39 infra and accompanying text.

19. Perry v. Sindermann, 408 U.S. 593 (1972); Board of Regents of State Colleges v. Roth, 408 U.S. 564, 577 (1972); Morrissey v. Brewer, 408 U.S. 471 (1972); see Bell v. Burson, 402 U.S. 535 (1971); Goldberg v. Kelly, 397 U.S. 254 (1970). See notes 40-43 infra and accompanying text.

20. Board of Regents of State Colleges v. Roth, 408 U.S. 564, 577 (1972); Perry v. Sinderinann, 408 U.S. 593, 603 (1972) (opinion of Burger, C.J., concurring). "[W] hether a particular teaclier [or other recipient of government benefits] in a particular context has any right to sucl administrative hearing hinges on a question of state law." Id. at 604. Justice Burger described his point as "underscoring" the opinions of the Court in Perry and Roth. Id. at 603. See note 41 infra and accompanying text.

21. Scarpa v. United States Bd. of Parole, 477 F.2d 278, 282 (5th Cir. 1973); United States ex rel. Bey v. Connecticut State Bd. of Parole, 443 F.2d 1079, 1086 (2d Cir.), vacated as moot, 404 U.S. 879 (1971); Menechino v. Oswald, 430 F.2d 403, 408 (2d Cir. 1970), cert. denied, 400 U.S. 1023 (1971). See notes 55-60 infra and accompanying text. 
clause $^{22}$ have been the basis for such a wealth of constitutional doctrine that it is helpful to catalog the different kinds of rights that have their source in that simple language. They can be roughly grouped into four categories: (1) "incorporated" rights, ${ }^{28}$ (2) "penumbral or natural law" rights, ${ }^{24}$ (3) "pure" procedural rights, ${ }^{25}$ and (4) substantive due process rights. ${ }^{26}$

Recent Court decisions ${ }^{27}$ have imposed a requirement that, as

22. ". . . nor shall any State deprive any person of life, liberty, or property, without due process of law ...." For a general discussion of the different kinds of rights which emanate from this clause, see Ratner, The Function of the Due Process Clause, 116 U. PA. L. REv. 1048 (1968).

23. After a long and sometimes heated dispute among various members of the Supreme Court, it is now beyond question that, apart from any other meaning the due process clause may have, it has made certain provisions of the Bill of Rights and their accompanying federal interpretations applicable to the states. See, e.g., Duncan v. Louisiana, 391 U.S. 145 (1968) (majority, concurring, and dissenting opinions); Griswold v. Connecticut, 381 U.S. 479, 507 (1965) (Black, J., dissenting). See also Williams v. Florida, 399 U.S. 78 (1970).

24. The due process clause now also guarantees against infringement by the states certain specific rights which do not appear in the text of the Constitution, for example, the right to privacy, Roe v. Wade, 410 U.S. 113 (1973), and the right to freedom of association, NAACP v. Alabama, 357 U.S. 449 (1958). Two doctrinal bases have been advanced to support this development. One theory holds that certain rights are penumbral to the first ten amendments, and have been incorporated just as the explicit provisions of those amendments lrave. Griswold v. Connecticut, 381 U.S. 479 (1965). The other explanation is that the concept of due process necessarily encompasses certain preferred freedoms to be gleaned from general principles of "natural law." Id. at 499 (concurring opinion of Harlan, J.). The states may adopt legislation whicl has the effect of discouraging the exercise of "incorporated" and "penumbral or natural law" rights only on a showing of some especially high level of justification-a "compelling State interest." See, e.g., Roe v. Wade, 410 U.S. 113, 155 (1973).

25. In its strictest and most literal sense, the due process clause simply requires that a state follow its own procedures; that is, a state must lrave authority for a deprivation of life, liberty or property in a statute which has been duly enacted and enforced according to its terms. This is apparently the sense in which the courts interpret the due process clause in the entitlement doctrine cases. See notes 75-88 infra and accompanying text.

26. In its broadest sense, the due process clause requires not only that a state's objective be permissible (not aimed at curtailing "incorporated" rights or "penumbral or natural law" rights) but also that the means cliosen to effectuate the objective be reasonable and plainly adapted to achieving it. See, e.g., Nebbia v. New York, 291 U.S. 502 (1934). Most cases that are commonly described as turning on questions of "procedural due process" could really be described as involving assertions of this right to substantive due process, for although the specific right claimed may be the right to have a certain procedure employed, the basis for alleging that this procedure is necessary must be that the present procedure adopted by the legislature (or lack thereof) does not reasonably effectuate the legislature's intended objective; and the validity of the legislative judgment about the proper means to a given end is, of course, a substantive issue. See discussion of cases 7 and 8 at notes 68-73 infra.

27. Perry v. Südermann, 408 U.S. 593 (1972); Board of Regents of State Colleges v. Roth, 408 U.S. 564 (1972); Morrissey v. Brewer, 408 U.S. 471 (1972); Fuentes 
an absolute precondition to a valid due process claim, the litigant must demonstrate that the state has invaded a "protected interest" in liberty or property:

[T]o determine whether due process requirements apply in the first place, we inust look not to the "weight" but to the nature of the interest at stake. We must look to see if the interest is within the Fourteenth Amendment's protection of liberty and property. ${ }^{28}$

As a practical matter, application of the protected interest requirement to assertions of "incorporated" and "penumbral or natural law" rights will have no effect, since this requirement will automatically be met: inherent in such claims is an infringement of the right asserted, and since the right involved is $a$ priori an interest protected by the due process clause, ${ }^{29}$ infringement of the right will necessarily invade solne "protected imterest." But for claims which cannot be linked to soine textual or metatextual provision of the Constitution other than the due process clause, so as to fall within the categories of "incorporated" rights or "penumbral or natural law" rights, ${ }^{30}$ the hurdle imposed by the new protected imterest test may be substantial.

In determining what constitutes a protected interest, the Court has given a broad construction to the word liberty. In addition to describing those guarantees of the Bill of Rights which have been in-

v. Shevin, 407 U.S. 67 (1972). Each of these cases involves the assertion of a "procedural" right, but since the claim of a right to a certain procedure is often a claim of a substantive right (see note 26 supra), there is no essential distinction between these cases and the substantive due process cases. Consequently, the protected interest analysis could theoretically be applied to them all. Moreover, the language typically used by the Court in announcing the protected interest concept is sweeping enough to encompass all claims under the due process clause. Consider, for example, the breadth of the quotation in the text accompanying note 28 infra. Thus the protected interest concept-and its corollaries, the entitlement and present enjoyment doctrines-may have potentially far-reaching impact.

28. Board of Regents of State Colleges v. Roth, 408 U.S. 564, 570-71 (1972) (citation omitted) (emplrasis in original).

29. "Incorporated" and "penumbral or natural law" rights are made applicable to the states because they are deemed to be inherent in the fourteenth amendment due process clause. Duncan v. Louisiana, 391 U.S. 145, 147-49 (1968). Altlough the Court has not explicitly so stated, a denial of these rights (such as free speech and privacy) should not be characterized as a deprivation of life or property; therefore, it must be a deprivation of liberty, the only remaining clioice offered by the clause. Even if one rejects the characterization of these rights as aspects of "liberty," the protected interest requirement will still be met: no matter how they are classified (as life, liberty, or property), "incorporated" and "penumbral or natural law" rights are by definition, interests protected by the due process clause. But cf. Justice Black's view that incorporated rights are made applicable to the states through the fourteenth amendment privileges and immunities clause. Id. at 166 (concurring opinion).

30. See notes 23 and 24 supra and accompanying text. 
corporated into the fourteenth amendment, ${ }^{31}$ "liberty"

denotes not merely freedom from bodily restraint but also the right of the individual to contract, to engage im any of the common occupations of life, to acquire useful knowledge, to marry, establish a home and bring up children, to worship God according to the dictates of his own conscience, and generally to enjoy those privileges long recognized . . . as essential to the orderly pursuit of happiness by free men. ${ }^{32}$

"Where a person's good name, reputation, lionor, or mtegrity is at stake because of what the government is doing to him," at least minimal due process safeguards must be observed. ${ }^{33}$ While the Court has declined to hold generally that the dismissal from a government job siguificantly infringes one's liberty ${ }^{34}$ (cases 1 and 2), "to be deprived not only of present government employment but of future opportumity for it certainly is no small injury," "35 and the Court might well find an infringeinent of liberty in such a case. Furthermore, "a State, in regulating eligibility for a type of professional eimployinent, cannot foreclose a range of opportunities [e.g., admission to the bar] in a manner . . . that contravene[s] Due Process." "36 Finally, the conditional liberty of a parolee "is valuable and must be seen as within the protection of the Fourteenth Amendment." ${ }^{37}$ Despite the Court's expansive interpretations of "liberty," there will be many aggrieved persons who cannot characterize the thing of which they have been deprived as an aspect of liberty, and who inust therefore contend with the entitlement doctrine.

31. See note 23 supra.

32. Meyer v. Nebraska, 262 U.S. 390, 399 (1923), cited with approval in Board of Regents of State Colleges v. Roth, 408 U.S. 564, 572 (1972).

33. Wisconsin v. Constantineau, 400 U.S. 433,437 (1971). "What the government was doing" to the plaintiff in Constantineau was publicly posting her name as an habitual drunkard to whom merchants should not sell liquor.

34. Board of Regents of State Colleges v. Roth, 408 U.S. 564, 573-74 (1972). However, the Court has hinted that liberty might be infringed if non-retention of a government employee would have a substantial adverse effect on his career. Id. at 574 n.13.

35. Joint Anti-Fascist Refugee Comm. v. McGrath, 341 U.S. 123, 185 (1951) (Jackson, J., concurring), cited with approval in Board of Regents of State Colleges v. Roth, 408 U.S. 564, 574 (1972).

36. Board of Regents of State Colleges v. Roth, 408 U.S. 564, 574 (1972), citing Schware v. Board of Bar Examiners, 353 U.S. 232, 238 (1957) (emphasis added). Sec Willner v. Commission on Character, 373 U.S. 96 (1963); Konigsberg v. State Bar, 353 U.S. 252 (1957).

37. Morrissey v. Brewer, 408 U.S. 471, 482 (1972); cf. Scarpa v. United States Bd. of Parole, 477 F.2d 278, 282 (5th Cir. 1973). But cf. Dorado v. Kerr, 454 F.2d 892, 896 (9th Cir.), cert. denied, 409 U.S. 934 (1972); Menechino v. Oswald, 430 F.2d 403, 409 (2d Cir. 1970) (dictum), cert. denied, 400 U.S. 1023 (1971). 


\section{Entitlement}

It has been in formulating a definition of property that the Court has developed the entitlement concept. The notion of an entitlement was first used as a vehicle for expanding the scope of due process protection. This process began when the Court was confronted with case $3,^{38}$ where the plaintiff was being denied a vital government benefit (welfare payments) which did not fit easily into traditional comunon law concepts of property. In ruling in his favor, the Court turned to the state's welfare statute, and found in its grant of benefits something sufficiently like property to trigger due process scrutiny:

[Welfare benefits] are a matter of statutory entitlement for persons qualified to receive them. Their termination involves state action that adjudicates important rights. The constitutional challenge cannot be answered by an argument that public assistance benefits are "a "privilege' and not a 'right.' "'

It may be realistic today to regard welfare entitlements as more like "property" than a "gratuity." Much of the existing wealth in this country takes the form of rights that do not fall within traditional common-law concepts of property. ${ }^{39}$

The Court did not consider what would happen if the state carefully tailored its statute to negate any inference that it was conferring a property right upon persons, like the plaintiff in case 3, whom it deemed ineligible.

When such a case did reach the Court (case $2,^{40}$ where the state had no tenure law that could provide the basis for an entitlement), it becaine apparent that the entitlement concept was a two-edged sword that could also be used to defeat due process claims:

To have a property interest in a benefit, a person clearly must have more than an abstract need or desire for it. He must have more than a unilateral expectation of it. He must, instead, have a legitimate claim of entitlement to it. . . . Property interests, of course, are not created by the Constitution. Rather they are created and their dimensions are defined by existing rules or understandings that stem from an independent source such as state law-rules or understandings that secure certain benefits and that support claims of entitlement to those benefits. ${ }^{41}$

38. Goldberg v. Kelly, 397 U.S. 254 (1970). See note 3 supra and accompanying text.

39. Id. at $262 \&$ n.8.

40. Board of Regents of State Colleges v. Roth, 408 U.S. 564 (1972). See note 2 supra and accompanying text.

41. Board of Regents of State Colleges v. Roth, 408 U.S. 564, 577 (1972). See Perry v. Sindermann, 408 U.S. 593, 603 (1972) (Burger, C.J., concurring). 
Thus, the Court held that teacher $A$ in case 1 had an entitlement grounded in the tenure provisions of the law of State $X$, and that the state had therefore invaded a "protected interest" by dismissing him;42 teacher $B$ on the other hand (case 2) had no contract, no tenure, and therefore no entitlement to reemployment under state law, and hence her dismissal without a hearing suffered from no constitutional infirmity. ${ }^{43}$ Thus, in orded to show a deprivation of property cognizable under the due process clause, an individual must have at least an arguable claim of right, under state law, to the thing of which he has been deprived.

\section{Right-Privilege Distinction Revisited?}

The dichotomy that the Court is emphasizing-between those plaintiffs who have a state law entitleinent and those who do notbears a close resemblance to the now judicially disapproved distinction between "rights" and "privileges." A long line of cases had held that due process guarantees were applicable to deprivations of "rights," but not to denials of mere "privileges."44 The reasoning was that what a state could deny altogether, it could withhold on whatever terms it chose. The rationale of the distinction has been demohished, ${ }^{45}$

42. Perry v. Sindermann, 408 U.S. 593 (1972). The plaintiff in Perry appealed from a decision granting the defendant's motion for summary judgment, and so he never had an opportunity to prove the existence of the de facto tenure agreeinent which he alleged. In reversing the affirmance of the motion and remanding the case to the district court, the Supreme Court held that proof of such an agreeinent "would obligate college officials to grant a hearing at his request, where he could be informed of the grounds for his nonretention and challenge their sufficiency." Id. at 603.

The implied-in-fact tenure approach may provide a route for circumventing the usual requirement of the entitlenent doctrine that the plaintiff show a right to employment rooted in statute or contract, but given the high standard of proof laid down by the Court (the plaintiff must show a "common law" of tenure, not a mere "expectancy" of continued employment, id. at 602-03), it seeuns likely that relatively few plaintiffs will be able to demonstrate the factual situation necessary to take advantage of it. And even plaintiffs who can prove such an agreement will be on no sounder theoretical footing in relying on the entitleunent doctrine than plaintiffs whose claim to an entitlennent is founded on statute or contract. See text accompanying notes 75-88 infra.

43. Board of Regents of State Colleges v. Roth, 408 U.S. 564, 579 (1972).

44. See Hamilton v. Regents of Univ. of Cal. 293 U.S. 245 (1934); Bailey v. Richardson, 182 F.2d 46 (D.C. Cir. 1950), aff'd by an equally divided Court, 341 U.S. 918 (1951); McAuliffe v. Mayor of New Bedford, 55 Mass. 216, 29 N.E. 517 (1892); Scopes v. State, 154 Tenn. 105, 289 S.W. 363 (1927).

45. See Van Alstyne, supra note 12; Note, The First Amendment and Public Employees-An Emerging Constitutional Right to be a Policeman, 37 GeO. WASH. L. Rev. 409 (1968); Comment, The Due Process Clause and Dismissal from Government Employment, 2 Houston L. REv. 120 (1964); Comment, Constitutional Rights of Public 
and the Court itself has explicitly rejected it many times. ${ }^{46}$ Yet, while decrying the wooden distinction between "rights" and "privileges," the Court has, somewhat contradictorily, sought to develop a similar if not identical construct sub nom. the entitlement doctrine, which distinguishes instead between "entitlements" and "unilateral expectations." Perhaps the exact degree of kinship between the doctrines, and the magnitude of the contradiction involved, will become clearer with future opinions. ${ }^{47}$

\section{Doctrine of Unconstitutional Conditions}

Surprisingly, if teacher $B$ were an imprudent and impudent radical whose vocal protests had angered the school board, she might yet have a right to a hearing in case $2 \mathrm{im}$ spite of her lack of an "entitlement," for she might then be able to argue that the state impermissibly conditioned her continued employment on the relinquishment of her constitutional right to freedom of speech. Such a claim would not be defeated by the lack of an entitlement to employment and the concomitant lack of a "protected interest" im property.

For at least a quarter century, this Court has made clear that even though a person has no "right" to a valuable governmental benefit and even though the government may deny him the benefit for any number of reasons, there are some reasons upon which the government may not rely. It may not deny a benefit to a person on a basis that infringes his constitutionally protected interests-especially, his interest in freedoin of speech. ${ }^{48}$

This is the familiar doctrine of "unconstitutional conditions":49 the state cannot punish a person for exercising a protected right by tak-

Employees: Progress Toward Protection, 49 N.C.L. Rev. 302 (1971); Comment, Another Look at Unconstitutional Conditions, 117 U. PA. L. ReV. 144 (1968).

46. See Board of Regents of State Colleges v. Roth, 408 U.S. 564, 571 (1972); Graham v. Richardson, 403 U.S. 365, 374 (1971); Bell v. Burson, 402 U.S. 535, 539 (1971); Shapiro v. Thompson, 394 U.S. 618, 627 n.6 (1969); Sherbert v. Verner, 374 U.S. 398, 404 (1963).

47. One possible analysis of the entitlement doctrine would be to attempt to equate it with the discredited right-privilege distinction and then cursorily dismiss it with a citation to a passage disapproving the latter in one of the very opinions in which the entitlement doctrine was enunciated. However, this Comment will analyze the entitlement doctrine and attempt to demonstrate its deficiencies imdependently, without reference to any possible kinship with the right-privilege distinction.

48. Perry v. Sindermann, 408 U.S. 593, 597 (1972).

49. See Hale, Unconstitutional Conditions and Constitutional Rights, 35 CoLUM. L. Rev. 321 (1935); O'Neil, Unconstitutional Conditions: Welfare Benefits with Strings Attached, 54 CALIF. L. Rev. 443 (1966); Van Alstyne, supra note 12; Note, Unconstitutional Conditions, 73 HARv. L. Rev. 1595 (1960). 
ing away his job or some form of governmental largess, ${ }^{50}$ notwithstanding the fact that he has no "protected interest" under the entitlement doctrine in the job or largess per se. The "protected interest" that is invaded is the aspect of liberty guaranteed by the infringed right.".1

As a practical matter, the protection afforded to the recipients of governmental benefits by resort to the unconstitutional conditions doctrine is severely limited by the problem of determining when the government has acted for an impermissible reason. To bring himself within the scope of the doctrine and be entitled to relief, the complainant must demonstrate a forbidden governmental purpose, yet it will often be impossible to discern the government's rationale when it need not, as a matter of course, give explanations for its actions. Of course, the aggrieved person can go to court and seek disclosure, but this is an expensive and unrealistic procedure in cases where there is no basis for even estimating the probability of success. ${ }^{62}$ The state might be required to provide a hearing every time there is a claim that it has acted for impermissible reasons, but such a requirement would undoubtedly encourage frivolous claims and would create just the sort of administrative burden that the courts have sought to avoid by limiting the availability of hearings through formulations such as the entitlement doctrine. ${ }^{53}$ Moreover, even an expanded unconstitu-

50. See Keyishian v. Board of Regents of the Univ. of the State, 385 U.S. 589 (1967); Sherbert v. Verner, 374 U.S. 398 (1963); Cafeteria Workers Local 473 v. McElroy, 367 U.S. 886 (1961).

51. See note 29 supra. The unconstitutional conditions cases are nore properly treated as arising directly under the provision of the Constitution guaranteeing the specific right infringed, albeit with the obligatory explanaton that the guarantee is made applicable to the states through the due process clause. The role of the due process clause in the incorporation and penumbra development processes probably accounts for the confusion of unconstitutional condition and "pure" due process claims which is often present in opinions. For examples of this confusion, see Connell v. Higginbotham, 403 U.S. 207 (1971); Pickering v. Board of Educ., 391 U.S. 563 (1968); Schware v. Board of Bar Examiners, 353 U.S. 232 (1957). All three cases are replete with free speecl issues, and thus are probably best viewed as raising first amendment, not due process, questions.

52. A claimant would "seek disclosure" by alleging in a complaint facts sufficient to constitute an unconstitutional condition claim, and then attempt to use discovery devices to obtain information about the basis of the government's decision, hoping thereby to support the allegation.

The difficulty is that, except in an unusual case where an impermissible govern. ment motive is fairly clear (e.g., a teacher fired immediately after leading anti-war denonstration) the would-be plaimtiff must undertake the burden of litigation on the chance that lie can uncover some impropriety, realizing that in many cases the government will have a legitimate basis for its action.

53. But see McDowell v. Texas, 465 F.2d 1342, 1347 (5th Cir. 1972), cert. denicd, 410 U.S. 943 (1973) (apparently holding that even an employee without an expectancy of reemployment must be given a hearing if he claims he is being terminated for a 
tional conditions doctrine would be inapposite in the vast majority of cases, where the governmental action complained of flows at most from mistake, not malice, so that the state cannot be considered to have acted for an impermissible reason..$^{54}$

\section{Present Enjoyment}

Cutting across the problem of defining what constitutes a "protected imterest" in property (under the entitlement doctrine) or in liberty, is another criterion, that of present enjoyment. It is not clear whether the present enjoyment doctrine works as an additional qualification to the protected interest test (that is, after showing a protected interest in liberty or property, the litigant must further show a presently enjoyed protected interest), or as an independent basis for invoking due process protection (that is, even if there is no protected interest, deprivation of a presently enjoyed benefit will trigger due process scrutiny). ${ }^{55}$ The present enjoyment requirement has been articulat-

constitutionally impermissible reason); contra George v. Board of Educ., 472 F.2d 132 (6th Cir. 1972) (holding that the government need not routinely grant such hearings on request, although the employee's unconstitutional condition claim is still cognizable in court).

54. A superficially appealing argument can be made that the unconstitutional conditions doctrine ought to be available to Ms. $B$ in her dispute with the school board, even if she is a political celibate. When $B$ signed her most recent one-year contract with the school board, the board, by failing to provide that it would grant a hearing to $B$ in case of a decision not to renew her contract, implicitly conditioned her employment on waiver of the right to a hearing in event of termination. Has the board not then unconstitutionally conditioned $B$ 's job on relinquishment of her due process right to a hearing? The difficulty is that, under the entitlement doctrine, in order to have a right to a hearing, $B$ must have been deprived of some entitlement rooted in state law. At the point when the board fails to renew her contract, of what has $B$ been deprived? She has no continuing contract and she has no tenure rights, so she cannot complain that the board's failure to renew has in itself deprived her of an entitlement to employment. But might she not have an entitlement to a hearing? An entitlement must be rooted in state law. But state law, as expressed in the board's policies, disclaims the existence of any right to a hearing, and the unconstitutional conditions doctrine will not work. The source of this circularity is the entitlement doctrine itself which, if apphed literally, allows the State to decide for itself what procedures it will follow no matter what the "protected interest" involved.

55. This ambiguity is due in large part to the courts' failure to make clear which principle is being applied. Since consistent application of the entitlement doctrine would result in a situation where no litigant could claim due process protection unless the state afforded it anyway, see text accompanying notes 75-88 infra, further restrictions on the availability of due process rights through the present enjoyment doctrine would seein superfluous. Instead, it seems more plausible to treat the present enjoyment doctrine as providing an alternative path for finding a "protccted interest" which might, at least in soine cases, obviate the effects of the entitlement doctrine. One case seems to indicate that the Second Circuit has adopted such a view, see note 60 infra. On the other hand, if the Fifth Circuit's reference to a "cognizable benefit" in the quo- 
ed by the Fifth Circuit en banc as follows:

The emerging and underlying principle is clear; once a cognizable benefit is conferred or received, governmental action must not be employed to deprive or infringe upon that right without some form of prior hearing. We are unaware, however, of any authority for the proposition that the full panoply of due process protections attaches every time the government takes some action which confers a new status on the individual or demies a request for a different status.

At least with respect to protected interests in property, the Supreme Court has concurred: "The Fourteenth Amendment's procedural protection of property is a safeguard of the security of interests that a person has already acquired in specific benefits." "57 So while it is clear that $A$ must get a hearing before his welfare benefits are terminated $^{58}$ (case 3), under the present enjoyment doctrine it is doubtful whether the state will be compelled either to grant $B$ 's initial application or give her a prompt hearing to determine her eligibility (case 4). While case 4 has apparently not yet been litigated, cases 5 and 6 (dealing with protected interests in liberty) have, and though $A$ unust be given a hearing on the revocation of his parole, ${ }^{50}$ poor $B$ may languish in prison for the full term of her sentence:

[an] essential element missing [im case 6] is the existence of a private interest enjoyed by appellant, or to which he is entitled, of the type qualifying for due process protection .... The type of interest protected by procedural due process . . . is usually one presently enjoyed. . . . Appellant, however, does not presently enjoy freedom of movement beyond the prison walls and nothing in the state court's sentence, or in state statutes or rules, entitles him to it, whether it be labeled a "right" or a "privilege." 60

tation in the text accompanying note 56 infra is taken to refer to an entitlement, then it would appear that that circuit has endorsed, at least in dictum, the theory that the present enjoyinent doctrine serves as an additional qualification to the protected interest test.

56. Scarpa v. United States Bd. of Parole, 477 F.2d 278, 282 (5th Cir. 1973). See Dorado v. Kerr, 454 F.2d 892 (9th Cir.), cert. denied, 409 U.S. 934 (1972); United States ex rel. Bey v. Connecticut State Bd. of Parole, 443 F.2d 1079, 1086 (2d Cir.), vacated as moot, 404 U.S. 879 (1971); Menechino v. Oswald, 430 F.2d 403, 408 (2d Cir. 1970), cert. denied, 400 U.S. 1023 (1971).

57. Board of Regents of State Colleges v. Roth, 408 U.S. 564, 576 (1972) (emphasis added).

58. Goldberg v. Kelly, 397 U.S. 254 (1970).

59. Morrissey v. Brewer, 408 U.S. 471 (1972).

60. Menechino v. Oswald, 430 F.2d 403, 408 (2d Cir. 1970), cert. denied, 400 U.S. 1023 (1971). The Menechino case seems to support the view that the entitlenent and present enjoyment doctrines provide alternative paths for finding a protected interest, in laying stress on the existence of "a private interest enjoyed by appellant, or 


\section{Circularity Run Rampant: The Illogic of}

\section{EnTtTLEMENT AND Present ENJoYment}

\section{Procedure or Substance?}

Underpinning the entitlement doctrine (and less clearly, the present enjoyment doctrine) is the notion that the task of defining the words "life," "liberty," and "property," as used in the fourteenth amendment, should be left to the states ${ }^{61}$-that while the federal courts may properly determine what the due process clause requires if it is applicable, the decision as to what relationships rise to the cognizable level of "liberty" or "property" is one of "substance," outside the allowable scope of judicial imquiry in "procedural" due process cases, and hence is to be left to the state legislatures. ${ }^{62}$ Such an approach would be eminently suitable in cases where the rights sought to be vindicated were purely "procedural," rendering decisions in this kind of due process case, the entitlement and present enjoyment doctrines would at least be externally consistent with the balance of due process law: the courts always would defer to the legislatures on questions of "substance."

The difficulty is that there is a large and growing body of cases

to which he is entitled. ..." Id. (emphasis added). See note 55 supra and accompanying text.

61. See Perry v. Sindermann, 408 U.S. 593, 603 (1972) (Burger, C.J., concurring).

62. In addition to resting on the doctrinal notion that liberty and property should be defined in terms of state law, the entitlement concept may be based as well on a corresponding practical notion about the role of the states in the federal system-that the federal judiciary should intervene as little as possible in relationships between a state and its citizens, and leave to the states the question of what procedures will best guarantee fair and equitable treatment. Application of the entitlement doctrine will clearly lead to such federal non-intervention in many cases, and it seems reasonable to attribute to the Court an intent to achieve the result that so plainly inheres in its decisions. A predilection for de-federalized standards was recently voiced explicitly in another context in Miller v. California, 413 U.S. 15 (1973) (obscenity to be determined by local community standards).

63. See note 25 supra and accompanying text. Since in "pure" procedural cases the litigant is only asking that the state observe its own procedures, it is completely consistent to leave to the state the determination of what quantum of interest in property or hiberty must be at stake before those procedures need comply with federal due process standards.

64. There might still be room left in such a scenario for "incorporated" and "penumbral or natural law" rights, see notes 23 and 24 supra and accompanying text, enforcement of which is straightforward and does not require the substitution of judicial for legislative discretion, at least not to the same extent as does the enforcement of substantive due process rights. See note 26 supra. The posited limitation would, of course, disallow the granting of substantive due process protection, and would therefore itself be inconsistent with many existing decisions, including those cited in note 65 infra. 
in which the judiciary, particularly the Supreme Court, has questioned the wisdom of the legislative judgment on substantive issues. Many of these cases $^{65}$ have involved the assertion of a right to a procedure (group 1), and hence to some extent are factually similar to the entitlement and present enjoyment procedural rights cases $^{60}$ in which the courts have refused to override the legislative judgment (group 2). ${ }^{67}$ The two groups of cases are thus inconsistent, in that they are factually similar, yet reach opposite holdings. Simce the entitleinent and present enjoyment doctrines are at the root of the courts' refusal to question the legislative judgment in the group 2 cases, the doctrines are a prime source of the imconsistency, and are therefore suspect. The inconsistency is not obvious, because it is not readily apparent that the courts have in fact engaged in substantive review of legislative judgments in the group 1 cases, since many of the opinions are written as if only procedural considerations are at work. A discussion of two of these group 1 cases will demonstrate their true substantive nature:

Case 7: $C$, who holds a valid driver's license in State $\mathrm{Y}$, is involved in an automobile accident. Under State Y's law, if $C$ does not make some showing of financial responsibility, his driver's hicense must be suspended pending the outcome of litigation with $D$, who was injured in the accident. $C$ has no insurance and declines to post security; therefore, the state suspends his

65. Vlandis v. Kline, 412 U.S. 441 (1973); Perry v. Sindermann, 408 U.S. 593 (1972); Morrissey v. Brewer, 408 U.S. 471 (1972); Bell v. Burson, 402 U.S. 535 (1971); Goldberg v. Kelly, 397 U.S. 254 (1970). In all of these cases except Vlandis, the Court at least superficially apphed the entitlement doctrine and found it no bar to overturning the challenged state procedures. That these cases are in fact properly classified as substantive due process cases-that is, that they involve judicial second-guessing of the legislature's judgment-will be demonstrated by the discussion of cases 7 and 8 at text accompanying notes 68-73 infra.

66. See, e.g., Board of Regents of State Colleges v. Roth, 408 U.S. 564 (1972); Scarpa v. Umited States Bd. of Parole, 477 F.2d 278 (5th Cir. 1973); Menechino v. Oswald, 430 F.2d 403 (2d Cir. 1970), cert. denied, 400 U.S. 1023 (1971).

67. This refusal has occurred both in the sense that the courts have refused to substitute federal for state interpretations of what constitutes liberty and property, and in the sense that the practical import of the decisions is to leave intact state procedural law.

The suggestion that the two groups of cases are similar refers only to the fact that both deal primarily with questions about the availability to the individual of some procedure. It is submitted, however, that this is a sufficient similarity to make the two groups of cases indistinguishable for the purposes of applying general principles of federal judicial deference to state decisions. For a discussion of whether there are differences between the cases along other lines of comparison, see text accompanying notes 74-81 infra. 
license. $C$ appeals, contending that the state, by depriving him of his license without a hearing on the issue of liability, has denied him due process of law.

These are the basic facts of an actual case, ${ }^{68}$ and the Supreme Court analyzed them as follows: $C$ has an entitlement to his driver's license under state law, and thus the state must afford him due process of law before depriving him of it. Due process requires a prior hearing on the question of whether there is some reasonable possibility that $C$ will be held liable, since the existence of such a possibility is the reason for the state's requirement that $C$ demonstrate financial responsibility. ${ }^{69}$ The case is thus cast into the standard "procedural due process" nold.

A more searching examination reveals, however, that case 7 actually involves a "substantive" issue. State Y's legislature, in failing to provide for a liearing, has expressed a judgment in the following form: there is a sufficient similarity between the situation of persons in class $P$ and persons in class $Q$ to justify treating them similarly. In this case, class $P$ consists of persons who are involved in automobile accidents and against whom there is a sufficiently high probability of a damage award being entered to justify requiring them to post a security bond as a condition of continued access to the public highways; class $Q$ consists of all persons who are involved in automobile accidents. The Court has, in effect, formulated a new class, $Q^{\prime}$ (actually a subclass of former class $Q$ which consists of persons who are involved in accidents and against whom an administrative officer has made some preliminary finding of liability at a hearing; it has allowed equation to class $P$ of only this more limited class $Q^{\prime}$. Seen in this light, the Court's superficially neutral "procedural" decicision really manifests a disagreement with the legislative judgment concerning the congruity of classes $P$ and $Q$, not merely a judicial mandate that the state must afford a hearing to an individual before revoking his driver's license.

Case 8: State $\mathrm{Z}$ operates a public university. It desires to give a subsidy to its own residents by charging them lower tuition. In order to sort residents from non-residents, the State creates an "irrebutable presumption" that persons applying to the university from other states are non-

68. Bell v. Burson, 402 U.S. 535 (1971). The claimant in Bell was probably the ideal plaintiff: a Georgia minister who needed his driver's license in order to commute between several widely separate parishes. Id. at 537.

69. Id. at 541. 
residents. $E, F$ and $G$ apply from out of state ${ }^{70}$ and are denied the special lower tuition rate, despite the fact that there is a significant link between each of them and State Z. ${ }^{71}$ They allege that the State's failure to give them a hearing on the issue of residence has infringed their "procedural due process" rights.

This too is an actual case in which the Supreme Court struck down the "irrebutable presumption" as violative of due process." As in case 7 it may be argued that this is actually a substantive decision. Here class $P$ consists of persons who have a sufficient connection with State $\mathrm{Z}$ to merit the subsidy, class $Q$ consists of all persons other than those who apply from other states, and class $Q^{\prime}$ consists of all those who have been determined to be residents at an administrative hearing. Yet the state is not forthrightly told that the Court disapproves of the imprecision of the classifying criteria used, but rather that making the classification at all without a hearing is improper. ${ }^{73}$

To reiterate, whether the questions they present be denominated procedural or substantive, cases 7 and 8 -as well as cases 1 ,

70. That is, they are physically living outside of the state at the time of their application. For example, $E$ may be an undergraduate at a college in a neighboring state who desires to transfer.

71. For example, $E$ could hold a driver's license from State $Z$, have his automobile registered in State $Z$, pay taxes in State $Z$, be registered to vote in State Z, and his parents could be undisputed residents of State $\mathrm{Z}$, and yet $E$ could be classified as a non-resident.

72. Vlandis v. Kline, 412 U.S. 441 (1973).

73. If the state could devise soine perfect classifying criterion that would precisely identify all those who have a sufficient nexus with State $Z$ to deserve the tuition discount, would a hearing still be required, open to consideration of what would then have to be extraneous factors? It probably would not, and this conclusion supports the inference that the real infirmity in case 8 is not the inere presence of an irrebutable presumption (and the absence of a hearing), but rather the grossly over- and under-inclusive nature of the presumption that was in fact used.

The Court recently struck down local school board rules which require pregnant teachers to take maternity leave four to five inonths prior to the expected birth, on the ground that these rules create an impernissible "irrebuttal presumption" that every teacher who is four or five inonths pregnant is incapable of performing her duties. Cleveland Bd. of Educ. v. LaFleur, 42 U.S.L.W. 4186 (Jan. 21, 1974). Mr. Justice Powell, in concurrence, recognized that the question was really one of substance, not procedure. "The constitutional difficulty is not that the boards atteinpted to deal with this problem by classifications." Id. at 4192 . Mr. Justice Rehnquist added in dissent:

All legislation involves the drawing of lines, and the drawing of lines necessarily results in particular individuals who are disadvantaged by the line drawn being virtually indistinguishable for many purposes from those individuals who benefit from the legislative classification. The Court's disenchantinent with 'irrebutable presumptions,' and its preference for 'individualized determination,' is in the last analysis nothing less thau an Id. at 4195 . 
3 and 5 (in which the Court ruled in favor of a right to a hearing) -arguably represent judicial incursions into the legislative province of weighing and balancing competing policies. To the extent, then, that the entitlement and present enjoyment doctrines are either theoretically or practically bottomed on general principles of federal judicial deference to the states in matters of "substance," the doctrines are simply inconsistent with a sizable number of nominally procedural, but actually substantive, due process decisions. The question remains, however, whether there are specific differences between cases $1,3,5,7$ and 8 , and cases 2,4 and 6 , which justify the differing treatment the two groups of cases have received.

\section{The Entitlement Doctrine Exposed}

With respect to the entitlement doctrine, the conclusion of this Comment is that there are no such differences between the cases, and that in fact any formulation of the doctrine that serves to defeat the claims in cases 2 and 4, must apply with equal force to cases 1, 3, 7 and $8,{ }^{74}$ defeating the claims in those cases as well, contrary to the Court's holdings. This is so because when the availability of due process protection is made to turn on state law, the state is given the ability to obviate completely what would otherwise be the requirements of the fourteenth amendment, and decide for itself what procedures to observe. $^{75}$ Thus in no case could a due process claim be upheld under the entitlement doctrine against the wishes of the state. ${ }^{70}$ Since rigid application of the doctrine would therefore read the due process clause out of the Constitution as a restraint on state action, and since inconsistent application of the doctrime, as presently occurs, ${ }^{77}$ can hardly be countenanced, it should be abandoned. ${ }^{78}$

74. Cases 5 and 6 , demonstrating the application of the present enjoyment doctrine, will be analyzed separately. See notes $94-96$ infra and accompanying text.

75. See text accompanying notes 79-88 infra.

76. An exception must be made for the trivial case where the state has already provided for the procedural right being sought; obviously this case would never be hitigated unless the state failed to observe the procedures it had set np. In that event, the case would probably be litigated in state court, but if the litigant did choose to proceed in federal court, the case would turn on "pure" procedural issues, see note 25 supra. In these limited circumstances, where the state has itself defined liberty or property to include both the benefit being denied and the sought-after procedures on the occasion of its denial, the entitlement doctrine would present no barrier to granting relief. Thus the statements in the text must be qualified somewhat: only "pure" procedural claims can be upheld under the entitlement doctrine.

77. Present application of the doctrine is inconsistent because the doctrine should operate to defeat the claims in cases $1,3,7$ and 8 , whereas the court held in favor of the claimants in those cases. See notes 79-81 infra and accompanying text.

78. See notes 113-16 infra and accompanying text. 
Reconsider cases $l$ and 2 . Recall that $B$ in case 2 could claim no due process rights because she had no entitlement to continued employment under the law of State X: she did not qualify for tenure, and she had no contract which would have been enforceable under state common law. Isn't $A$ in essentially the same position, contrary to the Supreme Court's holding in case 1? Aren't cases 1 and 2 really identical for purposes of applying the entitlement doctrine?

It is true that $A$, unlike $B$, had a right to employment under the tenure provisions of state law, and could be fired only for cause. That is, he could be fired only for cause as determined by the school board. ${ }^{79}$ State law, which gave $A$ his entitlement to employment, also specified the conditions and terms of that employment. One of the conditions was that $A$ would cease to have a riglit to employment if specified circumstances came to pass. Moreover, the decision that those circumstances existed was to be made in a certain way. The procedure provided by state law for making the decision did not involve a hearing; it allowed, instead, an ex parte determination by the school board. That procedure was complied with, and therefore $A$ was not deprived of anything that the terms of the tenure law-which gave $A$ his entitlement in the first place-did not contemplate would be taken away from him, should the school board act as it did. $A$ 's continued right to einployment was made contingent on the non-existence of cause for dismissal, as determined by the school board. Once the board decided that there was cause, $A$ no longer had any employment rights, so that the board's action in dismissing him deprived him of nothing le was entitled to under state law.

Of course, $A$ has a state claim that the scliool board has made an erroneous decision, but it is not that claim that he has chosen to press. He las instead relied on his federal right to due process of law. But under the entitlement doctrine, the existence of that right depends on the existence of a right to employment under state law, at the

79. This conclusion is not immediately apparent from the facts of case 1 , which are silent on exactly who is authorized by state law to decide when cause for dismissal exists. Logic dictates, however, that although cause may exist in the abstract, if it is to become the basis for action, it must be determined by some person or agency, and therefore state law must either explicitly or implicitly authorize someone to make that determination, the logical candidate in case 1 being the school board.

More generally, in every case where some benefit may be denied, there must be some administrative or judicial official authorized to make a decision on the issue of eligibility which will be binding until shown to be erroneous in some higher forum. Once the authorized official has made his decision on eligibility, then there is no longer any state law right to receive the benefit, and the official's further action in granting or denying the benefit is purely perfunctory. 
time of the board's action. Manifestly, if the board's finding that cause for dismissal then existed is upheld by the state courts (which is likely to be the case unless the decision was clearly erroneous), then $A$ had no such right, and no right to due process either. Thus, a rigid application of the entitlement doctrine to case 1 leads to a result exactly opposite that actually reached by the Court.

An analysis of case 7 (in which the Court found there was an entitlement) is similar. $C$ holds his driver's license subject to the implicit condition that it is revocable without a hearing if he is involved in an accident and does not show that he will be financially responsible for a judgment that might be entered against him. There is nothing particularly imvidious about this scheme, since the state could have permissibly "barred the issuance of licenses to all motorists who did not carry liability insurance or who did not post security." Wo When $C$ is involved in an accident, he has no reason to complain when the state summarily revokes his license after he fails to demonstrate his financial responsibility; he should have clearly understood that his license was, by its own terms, subject to defeasance in such circumstances. Correspondingly, since $C$ ceases to have an entitlement to a license under state law once the specified events occur, he cannot invoke the protection of the due process clause. ${ }^{81}$ Once again, strict application of the entitlement doctrime produces an outcome contrary to that reached by the Court.

Suppose the litigant's claim to some government benefit is founded not on a state statute, as in case 1, but on a contract enforceable under state common law. It has already been demonstrated that strict application of the entitlement doctrine to case 1 would defeat the due process claim just as in case 2 . Would a claim based on a contract fare any better? ${ }^{82}$

Case 9: $H$ is employed by State $\mathrm{X}$ under a contract providing that he can be dismissed by his superior for reasons

80. Bell v. Burson, 402 U.S. 535, 539 (1971).

81. By analogizing to real property law, one can regard $C$ in case 7 as having a fee simple determinable interest in his driver's license.

82. See Hostrop v. Board of Junior College Dist. No. 515, 471 F.2d 488 (7th Cir. 1972), cert. denied, 411 U.S. 967 (1973), where it is suggested that "[a] term of employment set by contract has been recognized as a property interest which the state cannot extinguish without conforming to the dictates of procedural due process." Id. at 494. Thus contract rights are in this context to be equated with statutory rights. Although the Hostrop court failed to apply the entitlenent test, the implication of its reasoning is that claims based on contract should be subject to the entitlement doctrine to the same extent as are claims founded on statute.

For a discussion of the relationship between federal due process rights founded on contracts and state contract rights, see id. at 494 n.15. 
specified therein. His boss $J$ fires him, citing one of these contract provisions.

There is no relevant distinction between this case and case 1 . In order to have an entitlement worthy of protection, $H$ must have an enforceable contract right to employment under state law. ${ }^{83}$ But since he has, in the opinion of his superior, fallen within one of the contract provisions allowing dismissal, and since his superior was empowered by the contract to make this determination, $H$ now has no enforceable contract-and no entitlement-to furnish a foundation for a due process claim, ${ }^{84}$ just as $A$ in case $I$ had no entitlement to employment once the school board determined, pursuant to statute, that cause for dismissal existed under the tenure law.

\section{The Fallacy of Entitlement}

The basic fallacy of conditioning the availability of due process protection upon the existence of an entitlement under state law flows from the fact that ultimately all property is a grant from the sovereign and exists only under such terms as the sovereign deems proper. $^{85}$ These is nothing in the entitlement doctrine that prevents the

83. Of course, $H$ could have an entitlement rooted in state statutory or case law, or even in an imphied-in-fact tenure agreement. Case 9 assumes that he does not, and that he must base his entitlement on a contract.

84. $H$ 's boss $J$ may be mistaken, and $H$ may be able to show this in state court; but unless the federal courts are willing to assume that $J$ will be wrong more often than he is right, once $J$ has determined that reasons for dismissal exist, $H$ 's entitlement must evaporate, pending state court review of $J$ 's determination.

85. The premise that all property exists as a grant from the sovereign is certainly not inconsistent with well-rooted traditions of Anglo-American jurisprudence. Cf. J. Bentham, Theory of Legislation, Principles of the Civil Code, Part I, 137-39 (Dumont ed. Hildreth transl. 1840). To this day all real property in England is held "of the Queen." A. Hargreaves, AN Introduction to the PRINCIPLes of LANd Law 29, 36 (3d ed. 1952). Even personal property has value in the economic sense only because the state recognizes the individual's imterest in it, and the state will use its monopoly of organized force to protect that interest. Cf. E. Seligman, Principles of EcoNOMICs 131-34 (1905). And all property is subject to being reclaimed by the state, for redistribution to another citizen who has proven to the state, through the judicial process, that equity requires that it be his as a quid pro quo for some detriment he has suffered. This is Aristotle's notion of rectifatory justice. See ArIstotne, THE ETHICs, bk. V., ch. 4, 114-17 (Ross transl. 1966). The state may require that property be transferred to it through the taxing process, because implicitly it has a preeminent claim to the rights it has created in the first place; and the state may appropriate property directly for public use through condemnation (subject to the fifth amendment requirement that "private property [shall not] be taken for public use, without just compensation.") See generally Michelman, Property, Utility and Fairness: Comments on the Ethical Foundations of 'Just Compensation' Law, 80 HARv. L. REv. 1165 (1967). It thus seems completely reasonable to treat not only intangible rights and status, but all property, as belonging to the individual only on the terms and conditions the state 
sovereign from defining those terms in such a way that the right to any particular "property" 86 that can properly fail in certain circumstances, will fail when those circumstances are determined to exist by any method the sovereign chooses. It matters not whether the prescribed method of determination comports with what one might assume to be the requirements of the due process clause; the "property" right will inexorably fail when the determination is made that conditions for defeasance exist. Once the "property" right fails, there is no longer any entitlement to support an invocation of due process safeguards, and a state may then proceed to reclaim such "property" from its citizen, free from the restraints of the due process clause. Carried to its logical extreme, the entitlement doctrine results in completely circular reasoning that contravenes the fourteenth amendment by allowing the states to determine that procedures are to be followed in dealings with their citizens without regard to federal standards.

Of course, even the most cursory reading of that amendment reveals that it is supposed to place some restraints on just such unfettered state action. ${ }^{87}$ Restraints are imperative to insure that the sovereign states wield fairly and equitably the enormous control they exercise over all forms of property. ${ }^{88}$ It stands reason on its head to say that due process guarantees do not apply, no matter how reasonable their application might be and how necessary they are to secure an individual's economic integrity, unless the state sees fit to define the terms of the granted entitlement to include those guarantees anyway.

\section{The Present Enjoyment Distinction Reconsidered}

Forget for a moment the inverted logic of the entitlement concept and reexamine the efficacy of the present enjoyment distinction as a boundary-drawing criterion. Consider again what the Supreme Court has said in connection with case 7: "If the statute barred the

imposes. See generally Hecht, From Seisin to Sit-In: Evolving Property Concepts, 44 BosT. U.L. REV. 435 (1964).

86. The word "property" is used here to denote not only real and personal property, but also intangible rights in all forms of government-controlled privileges and benefits.

The word any is italicized to emphasize the fact that, because even traditional forms of property are conceptually a grant from the state, the entitlement doctrine, carried to its extreme, would restrict the availability of due process protection for deprivations of even this sort of property.

87. What other intention could be inferred from the use of the language "No State shall ... nor shall any State deny ... nor deprive ..."? The entitlement doctrine, with its disingenuous interpretation of the words "life," "liberty" and "property," subverts the clear import of the language of the fourteenth amendment.

88. See note 85 supra. 
issuance of licenses to all motorists who did not carry libability insurance or who did not post security, the statute would not, under our cases, violate the Fourteenth Amendment." served:

Once licenses are issued, as in petitioner's case, their continued possession may become essential in the pursuit of a livelihood. Suspension of issued licenses thus involves state action that adjudicates important interests of the licensees. ${ }^{00}$

The Court correctly emphasizes the importance of the right to operate an automobile in modern society. But how is it that it is only "[o]nce licenses are issued" that they become "essential in the pursuit of a livelihood"? Clearly, the need for a license as an important concomitant of a full and active life is not necessarily any different for an initial applicant than for a hicense holder who is threatened with revocation proceedings. ${ }^{91}$

Similarly, in deciding case 3 (termination of welfare benefits), the Court noted with approval the opinion of the court below that, "to cut off a welfare recipient in the face of . . . 'brutal need' without a prior hearing of some sort is unconscionable . . . ." How is it any less unconscionable to deny an application without a hearing (case 4)? It inust be concluded that the present enjoyment distinction sinply cannot be justified on the basis of the disparate subjective need of the claimants.

Nor is the present value of the anticipated future stream of governmental benefits necessarily any greater to the person who has received them in the past than to the person who has not. Both will be deprived of the same thing if their right to the benefits (of whatever kind) is denied. ${ }^{.3}$

89. Bell v. Burson, 402 U.S. 535, 539 (1971).

90. Id.

91. See note 94 infra.

92. Goldberg v. Kelly, 397 U.S. 254, 261 (1970).

93. One could argue that the present recipient has a greater certainty of realizing his expected future benefits than does the mere applicant. But the present recipient must realize that these rights are subject to termination for a variety of reasons, and the applicant may justifiably expect that if he falls within the statutorily defined class, his rights will be recognized.

Imagine two similarly situated persons, $K$ and $L . K$ is presently receiving some government benefit, $L$ is not. Both $K$ and $L$ believe themselves to be within the class eligible for the benefit, and can convince a third person, $M$, of this. Assume (1) $M$ is completely rational; (2) the benefit-dispensing decision-making process has no inertial bias in favor of present recipients; rather, eligibility of all claimants is continuously reviewed and $M$ knows this; (3) decisional errors are randomly distributed between new applicants and present recipients. $M$ knows this as well; (4) $M$ believes 
Finally, compare cases 5 and 6 (parole). $A$, whose parole was revoked, may very well have had an expectation of continued freedom after two years, an expectation which furnishes a persuasive reason for protecting his interest in that freedom. ${ }^{94}$ The Supreme Court was sufficiently impressed with the importance of such an expectation to decide case 5 in $A$ 's favor. ${ }^{95}$ If the usual practice is to grant parole in five years, however, then after seven years of imprisonment, does not $B$, whose parole application has not yet been acted upon, have at least as great an expectation of freedom $?^{96}$ And who can say that the

that $K$ and $L$ are identical in respect to the relevant characteristics for receiving the benefits; (5) $M$ assumes that the courts will not employ the present enjoyment distinction to make $L$ 's claim harder to enforce.

If $M$ was to bid to buy the beuefits that $K$ and $L$ are henceforth to receive, in order to decide how much he should offer to pay, he would multiply the value of the benefits, if received (the same for both claimants), by the probability that each claimant would be held to meet the eligibility requirements, and thus receive the benefits in the future (the same for both, since they are supposed to be identical in respect to the relevant qualifications). $M$ would therefore offer to pay the same annount to both $K$ and $L$ : a bird in the hand is not necessarily worth two in the bush.

Thus, if a court must choose between protecting the interests of new applicants or the interests of present recipients, it is irrational to prefer the present recipients solely on the basis of an automatic, blanket assumption that their interests are nore valuable.

94. It might be argued that the present recipient of benefits should get preferred treatment because he may have relied to his detriment on his expectation that he would continue to receive the benefits. For example, $C$ in case 7 may have taken a job some distance from home, assuming that he will continue to receive the state's permission to drive. But the initial applicant sliould also be able to reasonably rely on his expectation that the benefit will be granted when requested by an eligible person. Johnny, who turns 18 tomorrow, may also take a similar job on the assumption that he can get a license promptly. If $C$ 's and Johnny's expectations are equally reasonable, then so is their reliance on those expectations. Of course, there may be extreme cases where the present recipients' reliance interest is so great as to deserve special protection. If $C$ accepts a job 80 miles away from his lome and works there for ten years, many would agree that his right to continue driving is more deserving of protection than is Johnny's right to get a hicense so he can begin his career at a similarly distant job site. The critical point is that $C$ would deserve preferential treatment in sucl a case not just because he presently holds a driver's license, but because a driver's license is so crucial to his welfare. The fact that the present recipient may, in some situations, have more at stake than the applicant, is a poor reason to assume that he always will.

95. Morrissey v. Brewer, 408 U.S. 471 (1972).

96. It might be objected that $B$ has no actual liberty of which she can be deprived, since she is in prison. This objection misses the mark. While it is true that $B$ has no present liberty that can be taken away, what she objects to is the denial of future liberty, whicli she claims she has a right to expect. Each and every moment, as future becomes present, $B$ is deprived of the liberty she claims. Deprivation is not a onetime occurrence that begins and ends at the moment when something is withdrawn; rather, it occurs continuously until the benefit that is the subject of the deprivation is restored or conferred.

Furthermore, even one who is in prison without possibility of imminent release can be deprived of certain aspects of liberty sufficient to invoke due process protection. 
prospect of future freedom to one who is free is more significant or more worthy of protection than the prospect of future freedom to one who is not?

\section{The Stakes: Government Largess, Preferred FREEDOMS, AND PROCEDURAL SAFEGUARDS}

\section{Implications of the Entitlement Doctrine}

One of the more striking developments in American society over the last forty years is the increasing concentration of economic power in the hands of government. ${ }^{97}$ While the economic well-being of most Americans has improved, that well-being has also become imcreasingly dependent on benefits controlled by government. ${ }^{08}$ Contemporaneously with these sweeping changes in the impact of government activity on the average person's life, the courts have shifted the focus of their most exacting scrutiny away from economic and property interests toward so-called preferred freedoms: freedom of expression and asso-

See Sostre v. McGinnis, 442 F.2d 178 (2d Cir. 1971), cert. denied sub nom. Sostre v. Oswald, 404 U.S. 1049 (1972).

97. While government has always had complete theoretical control over economic rights, see note 85 supra, in recent years this control has become more direct and effective, largely because the kinds of property that are on the ascendancy-intangible rights and status-naturally require a greater exercise of governmental control than do other forms of property which are readily subject to diffusion of control in the hands of individuals. This is so because control over tangible property can usually be manifested by possession without need for frequent policing of the rights involved; whereas even so familiar an intangible as a beneficial interest in a trust is likely to require an extensive system of governmentally created and enforced rules, and correspondingly greater government control, simply to define its terms and ownership. The dichotomy is even more apparent with respect to itens of largess such as welfare benefits, which, even if they theoretically "belong" to an individual, must be centrally administered. See Reich, The New Property, 73 Yale L.J. 733 (1964).

98. Consider the following forms of governinent benefits and the number of people they affect:

(1) general public welfare programs such as the G.I. Bill, Aid to Families with Dependent Children, and Social Security;

(2) direct subsidies, such as the farm price support program;

(3) indirect subsidies, effectuated through obscure but strategic provisions of the tax laws, such as the over-recovery of capital allowed to extraction industries through the depletion mechanism of section 613 of the Internal Revenue Code of 1954;

(4) government einployment;

(5) employment by firms having government contracts;

(6) licenses that are necessary to practice almost every profession and nany oceupations;

(7) franchises to operate businesses such as public utilities and television stations; (8) education and other traditional but rapidly-expanding areas of government
service.

The list is hardly exhaustive. See generally Reich, supra note 97. 
ciation, ${ }^{99}$ freedom from discrimination based on race and other personal characteristics, ${ }^{100}$ and freedom from interference with individual privacy. ${ }^{101}$

Unfortunately, when considered together, these trends make the Supreme Court's recent restrictions on the availability of due process protection under the entitlement doctrine especially regrettable. A person needs a stable and secure economic base from which to assert his preferred freedoms; in a real sense, property rights, broadly defined, are the predicate of all other rights. ${ }^{102}$ But im the absence of procedural safeguards against arbitrary government action, as people coine to depend upon government for an mcreasing proportion of their economic welfare, they will be less likely to "bite the hand that feeds them" by exercising their preferred freedoms in a manner which they think may be antagonistic to government interest.

Thus, in order to insure that the individual maintains the economic security necessary to fully exercise his preferred freedoins and political rights, it is imperative that imcreased government economic control be accompanied by adequate protection of the individual's interest in government benefits. The entitlement doctrine operates instead to seriously undercut the individual's position: he has no due process rights unless state law gives him an entitlement to them. ${ }^{103}$

99. See, e.g., Tinker v. Des Moines School Dist., 393 U.S. 503 (1969) (right of school children to wear black armbands in protest of Vietnam war); Cox v. Louisiana, 379 U.S. 536 (1965) (right of civil rights activists to demonstrate peacefully on public streets); Schware v. Board of Bar Examiners, 353 U.S. 232 (1957) (right of former coinmumist to take bar exam); Meyer v. Nebraska, 262 U.S. 390 (1923) (right of students to study German language in school).

100. See, e.g., Shapiro v. Thompson, 394 U.S. 618 (1969) (right of indigent welfare recipients to travel interstate); Levy v. Louisiana, 391 U.S. 68 (1968) (right of illegitimate children to inherit property); Douglas v. California, 372 U.S. 353 (1963) (right of indigent criminal defendants to transcript on appeal); Brown v. Board of Educ., 347 U.S. 483 (1954) (right of Negro children to equal education).

101. See, e.g., Roe v. Wade, 410 U.S. 113 (1973) (right of woinan to have abortion); Griswold v. Connecticut, 381 U.S. 479 (1965) (right of inarried couple to use contraceptives); Pierce v. Society of Sisters, 268 U.S. 510 (1925) (right of parents to send children to parochial schools). The courts' explanation for the dichotony between economic and preferred freedoms is that while those persons asserting economic interests can fend for themselves through the majoritarian political process, those asserting preferred freedoms often need protection from that process; and that, while the loss of economic freedom can be remedied through the pohtical process, the loss of preferred freedoms cannot, since the very freedoms lost are indispensible to influencing the institutions through which their recapture might be effected. See United States v. Carolene Prods. Co., 304 U.S. 144, 152 n.4 (1938) (Justice Stone's famous footnote).

102. See W. Lippman, The Method of Freedom 100-02 (1935).

103. However, the present enjoyinent doctrine may nonetheless establish an alterna- 


\section{The Importance of Sound Procedures}

What is being sought in the six cases posed at the beginning of this Comment, as in many actual cases, is not a decision on the inerits of the litigant's dispute with the government, but inerely a decree compelling the government to follow certain procedures in resolving the dispute-procedures which at a minimum would include the government's listening to the litigant's claim and stating the reasons for its decision. This procedural protection may appear to be slight indeed, for even if they are forced to hear the facts, administrative bureaucrats will still be vested with broad discretion, and although they theoretically must act "reasonably" if due process protection attaches, courts are reluctant to reverse administrative decisions. ${ }^{104}$ Procedural guarantees cannot overcome unwise laws or regulations prescribed by ignorant, venal, or illiberal policy-makers. ${ }^{105}$ What good is a hearing if the result may well be the same with as without one? What of the need to protect the individual's economic position in his relations with the government?

"It is significant that most of the provisions of the Bill of Rights are procedural, for it is procedure that marks mucl of the difference between rule by law and rule by fiat." tend to (1) put into the hands of the decision-maker a broader range of information about the issue under consideration, (2) reveal honest mistakes so that they can be corrected, (3) expose some irrational decisions to public view and criticism, making such decisions less likely in the future, (4) help expose impermissible reasons for decisions, providing a basis for hitigation, (5) promote the consistency of decisions, and (6) inspire public confidence that decisions are reached fairly and that there is a "place to go" with grievances.

\section{Consequences of thie Present Enjoyment Distinction}

The present enjoyment distinction threatens to produce a somewhat unexpected result. If state authorities are forced (as in fact they

tive basis for invoking due process protection. See note 55 supra and accompanying text.

For a discussion of the implications of the present enjoyment doctrine, see note 107 infra and accompanying text.

104. Cf. Reicl, supra note 97, at 749-52. But cf. Pickering v. Board of Educ., 391 U.S. 563 (1968); Slochower v. Board of Educ., 350 U.S. 551 (1956).

105. The suggestion is not that all policy-makers possess these qualities, or even that many do, but only that unwise statutes and regulations will occasionally be promulgated.

106. Wisconsin v. Constantineau, 400 U.S. 433,436 (1971). 
may be now) to grant cumbersome procedural safeguards to those from whom they wish to take a presently enjoyed benefit, but can deny applications for benefits summarily, they understandably may seek to investigate apphicants more fully, make eligibility criteria stiffer, and reject marginal applicants, in order to minimize the danger that many ineligibles will receive benefits which cannot readily be cut off. Thus the state response may exacerbate the differing treatment of initial applicants and present recipients. ${ }^{107}$

\section{Explanations That Fail to Explain: JUDICIAL RATIONALIZATION?}

It is difficult to perceive why the courts should choose to decide cases on the basis of the entitlement and present enjoyment doctrines, simce other more straightforward bases for decision exist. ${ }^{108}$ Both doctrines are built on elusive distinctions, suffer from circular reasoning, and have been imconsistently applied by the courts that formulated them. ${ }^{109}$ It is not unfair to say that the opinions simply fail to explain the differences between the cases. Why, then, have the courts utilized the entitlement and present enjoyment concepts?

It might be concluded that the entitlement and present enjoyment doctrines are examples of "judicial rationalization." That is, they represent attempts to announce decisions in terms of suitably judicial bright-line criteria (you either have an entitlement or you don't), instead of exposing the weighing and balancing of interests that may actually have been used in reaching the result. A court might indulge im such rationalization in order to avoid the somewhat unseemly appearance of engaging in "judicial legislation." Of course, any conclu-

107. Thus the end result of today's decision [Goldberg v. Kelly, 397 U.S. 254 (1970)] may well be that the government, once it decides to give welfare benefits, cannot reverse that decision until the recipient has had the benefits of full administrative and judicial review, including, of course, the opportunity to present his case to this Court. Since this process will usually entail a delay of several years, the inevitable result of such a constitutionally imposed burden will be that the government will not put a claimant on the rolls initially until it has made an exhaustive investigation to determine his eligibility. While this Court will perhaps have insured that no needy person will be taken off the rolls without a full "due process" proceeding, it will also have insured that many will never get on the rolls, or at least that they will reinain destitute during the lengthy proceedings followed to determine initial eligibility. Id. at 279 (Black, J., dissenting).

The answer to the problem posed by Justice Black is that, in soine cases at least, the government should not be able to deny benefits to new apphicants nntil it has given them a due process opportunity to show their ehgibility. Such a conclusion does, however, require rejection of the present enjoyment distinction.

108. See notes 121-25 infra and accompanying text.

109. See notes 61-96 supra and accompanying text. 
sion about the reasoning process of judges must be speculative, but the inconsistency and circularity of the doctrines are not otherwise easily explained.

The dangers of judicial rationalization, if it is in fact at work in the formulation of the entitlement and present enjoyinent doctrines, are twofold. Public consternation may result from the failure of judicial opinions to explain persuasively the distinctions between the cases which justify different treatment. More significantly, when the time comes to decide subsequent, similar cases in which the true, underlying balancing of interests would lead to a different result, but the superficial rationale dictates summary treatment based on precedent, a court inust either render a decision inconsistent with the principle it has articulated or be trapped into a decision contrary to the actual equities of the case. ${ }^{110}$

\section{Conclusion: Life, Liberty, Property and Balancing}

The thrust of this Comment is that the entitlement and present enjoyment doctrines should be abandoned, a conclusion which is bolstered by the recent decision in Fuentes $v$. Shevin. ${ }^{111}$ In striking down a state's summary replevin procedure which allowed repossession of goods without prior notice or an opportunity to be heard, the Court held in Fuentes that it is not necessary to have the right of ultimate ownership of a thing in order to be entitled to due process protection before being deprived of it. The fourteenth anendment, said the Court, protects not only undisputed rights of ownership. ${ }^{112}$ Reasoning by analogy, when a state is a party to a dispute concerning an individual's right to a particular benefit, the fact that the individual lacks an undisputed right to the benefit-because the state claims he has no such right - should not be a sufficient reason for the state to be able to deprive him of the benefit without due process of law.

\section{Life, Liberty, and Property as an Exhaustive Categorization}

Two doctrines have been analyzed here by means of which the courts have denied due process protection to persons who have suffered

110. See generally Wechsler, The Courts and the Constitution, 65 Colum. L. REv. 1001 (1965); Wechsler, Toward Neutral Principles of Constitutional Law, 73 HARv. L. Rev. 1 (1959).

111. 407 U.S. 67 (1972).

112. Id. at 86-87. Ownership of the goods was in dispute in Fuentes because the seller under a conditional sales contract claimed that the buyer had defaulted on payments, and that therefore the seller had the right to possession. Nevertheless, the Court held that the state could not aid the seller in reclaiming the goods without affording the buyer an opportunity to contest the seller's claim. Id. 
a real detriment at the hands of government, on the theory that there has been no deprivation of life, liberty, or property within the meaning of the fourteenth amendment. Both doctrines ought to be abandoned, one because it would threaten to wipe out the due process clause if logically applied, ${ }^{113}$ the other because it would skew the availability of governmentally-provided benefits in favor of those already receiving them, ${ }^{114}$ preservimg a possibly inequitable status quo. Perhaps of even greater importance, abandoning the doctrines and replacing thein with a balancing test which would accurately articulate the true reasoning underlying the decisions, would prevent the proliferation of judicial rationalization that might be necessary to sustain the doctrines and would lay a sounder conceptual groundwork for the developinent of future due process law. ${ }^{115}$ And so, it is in order to commend again the simple principle proposed at the outset: regard life, liberty and property as encoinpassing everything of which a person can be deprived, and hold that a person has a claim withm the ambit of the due process clause whenever governmental action has accrued to his detriment. If lie has standing and a state is a party, consider his claim. ${ }^{116}$

\section{Two Caveats}

Adoption of this suggestion would not mean two things. It would not mean that the state government would have to afford "just compensation" every time it denied a person some benefit. The standards for showing a claim cognizable under the just compensation clause ${ }^{117}$ have always been, and would continue to be, different, and usually stricter, than the standards for showing a claim cognizable under the due process clause. ${ }^{118}$

Second, adoption of an expansive reading of "life, liberty, or prop-

113. See notes 75-88 supra and accompanying text.

114. See notes 89-96 supra and accompanying text.

115. See text accoinpanying notes 108-10 supra.

116. The claim referred to is not the litigant's claim that the state has wrongfully deprived him of some benefit, but rather his claim that the state has reached its decision in a way not complying with the requirements of due process. It is the merits of this claim-that the state should be compelled to follow a certain procedure in the factual context in issue, and others like it - that the courts should usually consider, without regard to the threshold question of whether the state has invaded a "protected interest." The clain of wrongful deprivation, challenging the substantive correctness of the state's decision, would be resolved in state tribunals, after any federally-mandated procedures had been complied with.

117. ". . . nor shall private property be taken for public use, without just compensation." U.S. CoNST. amend. V.

118. See, e.g., Miller v. Schoene, 276 U.S. 272 (1928); Pennsylvania Coal Co. v. Mahon, 260 U.S. 393 (1922). 
erty" would not necessarily result in a vast multiplication of the number of situations where hearings are required, hamstringing the oper'ations of the governmental agencies, for "[d]ue process is an elusive concept. Its exact boundaries are undefinable, and its content varies according to the specific factual context."119 Thus, even though the claimant could bring himself within the ambit of the due process clause almost automatically, due process "does not require a trial-type hearing in every conceivable case of government infringement of private interest."120

\section{What Process is Due?}

The question remains, how the courts are to sort from the multiplicity of cases that would be brought within the scope of the due process clause by adoption of the principle suggested, those cases in which some minimal protection-at least an opportunity for a prior hearing-is to be required. Any hard and fast rule would probably prove susceptible to dissection; balancing of interests will inevitably be necessary. Some relevant considerations are:

(1) How essential is the thing being denied to the person's survival, livelihood, or ability to assert his other rights? ${ }^{121}$

119. Hannah v. Larche, 363 U.S. 420,442 (1960). Since the suggested principle would mean that more cases would qualify for due process scrutiny, it might be criticized on the ground that to hear these claims would increase dramatically the workload of the federal courts. But the implied alternative-leaving a right without a remedy merely to alleviate docket crowding - can hardly be countenanced. Cf. Swann v. Charlotte-Mecklenburg Bd. of Educ., 402 U.S. 1, 22 (1971).

120. Cafeteria Workers Local 473 v. McElroy, 367 U.S. 886, 894 (1961) (hearing not required upon revocation of security clearance of private employee, who, because of revocation, could not obtain access to place of work, where employee could readily obtain similar employment elsewhere); see Phillips v. Commissioner, 283 U.S. 589, 597 (1931) (hearing not required prior to compelling taxpayer to pay disputed taxes, where opportunity for ultinate administrative and judicial hearing on tax liability provided).

In McElroy and Phillips, the Court first held that due process guarantees were generally applicable, and then proceeded to balance competing interests in deciding exactly what guarantees were applicable. The ultimate result in each case happened to be the same as if the entitlement doctrine had been applied to defeat the claim altogether; but at least the Court considered the individual equities of the cases.

121. The extent to which procedural due process must be afforded the recipient is influenced by the extent to which he may be "condemned to suffer grievous loss," and depends upon whether the recipient's interest in avoiding that loss outweighs the governmental interest in summary adjudication. Goldberg v. Kelly, 397 U.S. 254, 263 (1970), quoting Joint Anti-Fascist Refugee Comm. v. McGrath, 341 U.S. 123, 168 (1951) (Frankfurter, J., concurring).

Cf. Boddie v. Connecticut, 401 U.S. 371 (1971). A crucial factor in the Boddie Court's decision that due process mandates a waiver of court access fees for indigent parties seeking divorce was the fact that the interest at stake was petitioner's associa- 
(2) To what extent is the thing denied one that the individual could have secured for himself, in the absence of governmental presence in the affected area? Consider the difference between government licensing and government einployment: a person could be a doctor even if there were no state, but he could not be a state-enployed doctor without it. ${ }^{122}$

(3) How reasonable is the person's rehance on his expectation that he would have the thing at the time it was denied? Is the thing one that is routinely or rarely given? Applications for licenses to drive an automobile and to sell liquor might properly receive different treatment. ${ }^{123}$

(4) What is the burden on the government in providing non-summary adjudication? Specifically,

(a) What is the cost in administrative resources?

(b) What is the cost to the public treasury in providing the thing during the adjudication period? If a hearing prior to denial is mandated, even new applicants might liave to be provided the thing wlile awaiting adjudication, if adjudication is not reasonably prompt.

(c) What is the detriment to public welfare in providing the thing during the adjudication period? A parolee who has reverted to his old habits might be a public menace.

(d) If the thing is something the government need not provide at all, what is the danger that the burden in non-summary adjudication will be so great that the government will discontinue providing it altogether? ${ }^{124}$

tional right in the dissolution of his marriage. United States v. Kras, 409 U.S. 434, 44345 (1973).

Professor Reich has pointed out that the courts often balance the "individual interest" with the "public interest," with the predictable result that the individual generally loses. Instead, according to Reich, the courts should recognize that it is in the "public interest" that the iudividual be secure in his property holdings and rights, so that the factors which are usually placed on opposite sides of the balancing equation-public welfare and individual economic welfare-may actually both belong on one side, that of providing the due process safeguard in question. Reich, supra uote 97, at 776-77.

122. See Van Alstyne, supra note 12. The point made is that the courts should be more vigilant in protecting the kind of property interests and rights that an individual could have secured for himself (e.g., the right to practice an occupation), as differeutiated from those that are possible only because of the existence of government (e.g., the right to receive government paychecks).

123. But see Hornsby v. Allen, 326 F.2d 605, 610 (5th Cir. 1964), where due process protectiou was invoked on behalf of an applicant for a liquor license.

124. For a preeminent example of the sort of balancing here coutemplated, see Dixon v. Alabama State Bd. of Educ., 294 F.2d 150 (5th Cir.), cert. denied, 368 U.S. 
Such a flexible, balancing approach to due process cases will not be easy to apply, but it will probably produce better-reasoned decisions than have the entitleinent and present enjoyment doctrines, and will help fulfill for more people the promise that has been a part of our juridical heritage since the Magna Carta:

No freeman shall be taken, or imprisoned, or be disseised of his Freehold, or Liberties, or free customs, or be outlawed, or exiled or any other wise destroyed; nor will we not pass upon him nor [condemn him], but by lawful judgment of his Peers, or by the Law of the Land.125

930 (1961), which outlines what procedures must be followed on dismissal of a student from a state college.

125. 29 MAGNA CARTA, 25 Edw. I, ch. 29 (1297). 